\title{
CONTENT MANAGEMENT SYSTEM ZPRENEUR IN SUPPORT OF ENTREPRENEURSHIP ILEARNING AT PERGURUAN TINGGI RAHARJA
}

\author{
Qurotul Aini ${ }^{1}$ \\ Indri Handayani ${ }^{2}$ \\ Cahyo Anggoro Seto ${ }^{3}$ \\ Email:aini@raharja.info,indri@raharja.info,cahyo@raharja.info \\ Diterima : 05 Januari 2015 / Disetujui : 23 Januari 2015
}

\begin{abstract}
Students are not only provided a knowledge of soft skills for studying in lecture bench, but also trained in how to build the entrepreneurial spirits to face the competition of globalization. Each college also has a different method in building students entrepreneurial spirits. In the practice of entrepreneurship courses in Perguruan Tinggi Raharja, the students perform entrepreneurial activity in a way that is still very conventional. Where they are assigned to sell a product within the scope of the campus. Seeing how the conventional sales process and marketing reach is limited, then digagaskanlah an alternative solution to the entrepreneurial activities by utilizing the development of information and communication technology. Zpreneur content management system is a good solution for students perform entrepreneurial activities. Where zpreneur provide a forum for students to sell their products online. Each student can have their own online store on zpreneur system. That way, they can market their products online, and of course develop their market share not only in the scope of the campus.
\end{abstract}

Keywords: Ecommerce, Zpreneur, Entrepreneurship

\section{ABSTRAK}

Mahasiswa bukan hanya dibekali sebuah ilmu soft skill selama menempuh pendidikan di bangku perkuliahan, akan tetapi juga dilatih bagaimana cara membangun jiwa entrepreneurship guna menghadapi persaingan globalisasi. Setiap perguruan tinggi pun mempunyai metode yang berbeda-beda dalam membangun jiwa entrepreneurship para mahasiswanya. Dalam praktek mata kuliah entrepreneurship di Perguruan Tinggi Raharja, para mahasiswa melakukan kegiatan entrepreneurship dengan cara yang masih sangat konvensional. Dimana mereka ditugaskan menjual sebuah produk dalam ruang lingkup kampus. Melihat bagaimana proses penjualannya yang konvensional dan jangkauan pemasaran yang terbatas, maka digagaskanlah sebuah alternatif pemecahan masalah untuk kegiatan entrepreneurship tersebut dengan memanfaatkan perkembangan teknologi informasi dan komunikasi. Content management system zpreneur merupakan sebuah solusi yang baik bagi para mahasiswa melakukan kegiatan entrepreneurship. Dimana zpreneur menyediakan wadah bagi para mahasiswa untuk menjual produknya secara online. Setiap mahasiswa dapat memiliki toko online mereka sendiri pada sistem zpreneur. Dengan begitu, mereka dapat memasarkan produk mereka secara online, dan tentunya mengembangkan pangsa pasar mereka bukan hanya pada ruang lingkup kampus.

Kata Kunci : Ecommerce, Zpreneur, Entrepreneurship

Vol.8 No.3 - Mei 2015 


\section{PENDAHULUAN}

Perkembangan ilmu pengetahuan yang pesat diikuti oleh kemajuan teknologi informasi. Melalui teknologi informasi seseorang dapat memperoleh informasi dengan cepat dan mudah. Salah satu produk teknologi informasi yang cukup banyak digunakan saat ini adalah internet. Internet menghubungkan ribuan bahkan jutaan jaringan komputer diseluruh dunia, sehingga memungkinkan setiap komputer yang terhubung dapat melakukan komunikasi satu sama lain. Seluruh jaringan komputer dalam internet dapat saling berkomunikasi dengan menggunakan standar protokol yang secara resmi dikenal dengan TCP/IP (Transmission Control Potocol/Internet Protocol). Internet telah menyentuh berbagai sektor bidang kehidupan manusia mulai dari sektor bisnis, edukasi, entertain, dan lain sebagainya. Pemanfaatan internet dalam dunia pendidikan merupakan alat bantu yang cukup baik dalam memperbaiki sistem pembelajaran yang belum optimal.

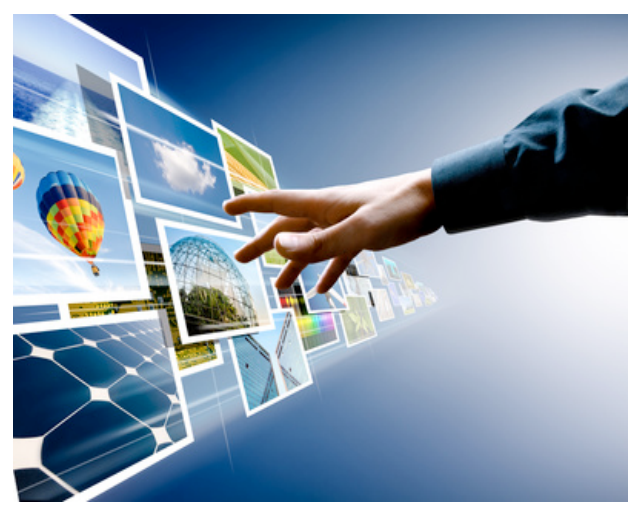

\section{Gambar 1. Perkembangan Teknologi Informasi dan Komunikasi}

Dalam kegiatan belajar di universitas atau perguruan tinggi, seorang mahasiswa harus membiasakan diri dengan cara baru dalam mengikuti pendidikan. Mahasiswa dituntut maksimal mampu menyerap materi yang telah diajarkan dosen dalam perkuliahan. Membaca berbagai literatur yang berkaitan dengan topik yang disampaikan oleh dosen akan memberikan pemahaman yang komprehensif dan memperluas wawasan. Oleh karna itu, mahasiswa harus berupaya untuk berintegrasi dengan teknologi. Teknologi informasi sebagai perpaduan antara teknologi komputer dan komunikasi membuat perubahan dalam melakukan sesuatu, termasuk cara dalam mengidentifikasi dan mendapatkan informasi bagi para mahasiswa.

Perguruan Tinggi Raharja adalah sebuah lembaga pendidikan yang berfokus pada bidang IT (Information Technology). Oleh karena itu, sebagai salah satu perguruan tinggi yang bergerak dalam bidang komputer, perguruan tinggi raharja senantiasa berinovasi dalam meningkatkan kualitas pembelajaran yang mampu memanfaatkan perkembangan teknologi informasi saat ini dalam kegiatan belajarnya. Salah satunya dengan menerapkan sistem pembelajaran i-Learning. Metode i-Learning diciptakan oleh Ir. Untung Rahardja pada tahun 2009. Dimana metode tersebut bukan hanya mengajak mahasiswa untuk belajar, tetapi juga menyatukan beberapa unsur didalamnya yaitu, bekerja, bermain dan berdoa tau biasa disebut dengan istilah 4B.

Sistem pembelajaran iLearning yang dirancang amat efisien, praktis dan menyenangkan mampu menimbulkan antusias dan semangat belajar para mahasiswa. Dengan dukungan teknologi yang dapat mempermudah mahasiswa dalam pembelajaran dan menyerap informasi, diharapkan meningkatkan hasil belajar para mahasiswa. Sistem pembelajaran ini dapat diimplementasikan sebagai infrastruktur $4 \mathrm{~b}$ iLearning seperti gambar dibawah ini : 


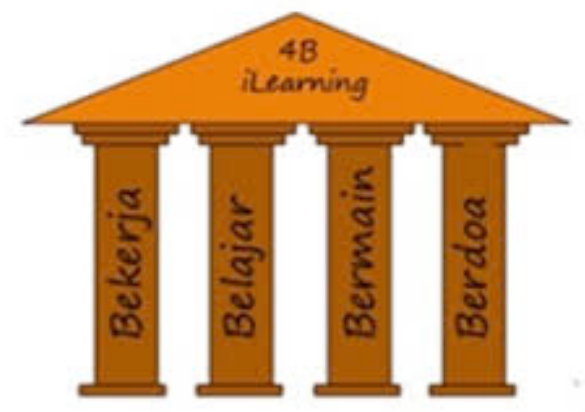

Gambar 2. Infrastruktur iLearning.

\section{LANDASAN TEORI}

\section{Definisi TPi (Ten Pilar IT iLearning)}

Untuk memudahkan pengelolaan dan meningkatkan kepuasan pelayanan kepada sivitas akademika Perguruan Tinggi Raharja terutama dalam mendukung perkuliahan menggunakan metode iLearning maka perlu adanya 10 Pillar IT iLearning Perguruan Tinggi Raharja. Output yang diperoleh adalah merupakan hasil dari penelitian Tridarma Perguruan Tinggi antara dosen dengan mahasiswa yang diwadahi oleh Raharja Enrichment Centre.

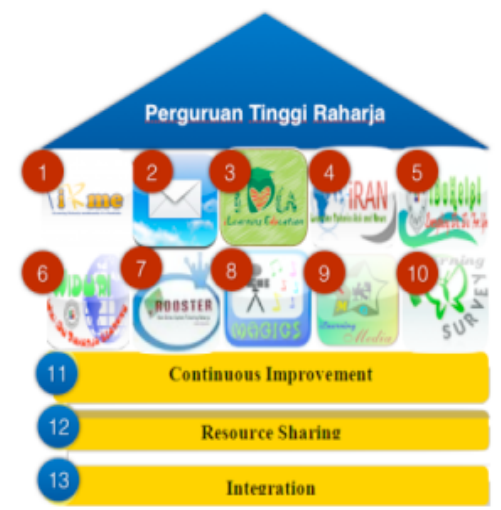

Gambar 3. Infrastruktur TPi IT iLearning.

Sistem arsitektur pada Perguruan Tinggi Raharja yang termasuk kedalam TPi (Ten Pilar IT iLearning) adalah sebagai berikut : iRme(iLearning Raharja Multimedia e-Portfolio), Rinfo (email
Raharja.info), iDU (iLearning Education), iRan (iLearning Raharja Ask \& News), iDuHelp!, Widuri (Wiki iDU Raharja iLearning), Rooster (Role Online System Ticketing Raharja), Magics (Multimedia Audio Gallery iLearning Community And Services), iMe (iLearning Media), iSur (iLearning Survey).

\section{Definisi iLearning (Integrated Learning)}

Menurut Untung Rahardja [2011](1)iLearning adalah mengintegrasikan sumber daya dalam menjalankan dalam menjalankan Tri Dharma Perguruan Tinggi dengan menggunakan iPad, dimana iPad memiliki aplikasi pendukung pembelajaran dan masih banyak lainnya.

Sistem iLearning yang ada sudah cukup baik, namun belum efektif dan beragam karena pelaksanaan ujiannya masih terpaku pada konsep paper based. Dengan menggunakan konsep computer based saat pelaksanaan ujian akan menentukan mutu kualitas dalam proses pembelajaran iLearning.

\section{Definisi Zpreuner Airzone}

Dikutip dari Widuri, Zpreuner adalah Sistem ecommerce airzone yang dikembangkan dengan menggunakan model sistem ecommerce B2C. Berupa OpenSource Wordpress yang di kembangkan di Perguruan Tinggi Raharja guna mendukung kegiatan/aktivitas praktek entrepreunership pada matakuliah entrepreneur. Sama halnya seperti Ecommerce System yang sedang ramairamainya di dunia maya. dimana Zpreuner mampu menyediakan toko online sendiri bagi masing masing seller, sehingga tiap seller di Zpreuner mampu membangun toko onlinenya masing-masing. 


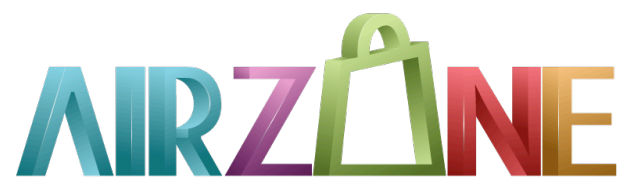

Gambar 4. Logo Zpreuner Airzone.

\section{Definisi Wordpress}

WordPress adalah sebuah aplikasi sumber terbuka (open source) yang sangat populer digunakan sebagai mesin blog (blog engine). WordPress dibangun dengan bahasa pemrograman PHP dan basis data (database) MySQL. PHP dan MySQL, keduanya merupakan perangkat lunak sumber terbuka (open source software). Selain sebagai blog, WordPress juga mulai digunakan sebagai sebuah CMS (Content Management System) karena kemampuannya untuk di modifikasi dan disesuaikan dengan kebutuhan penggunanya. WordPress adalah penerus resmi dari b2/cafelog yang dikembangkan oleh Michel Valdrighi. Nama WordPress diusulkan oleh Christine Selleck, teman ketua pengembang(developer), Matt Mullenweg.

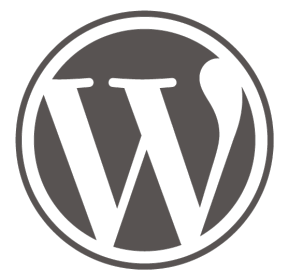

Gambar 5. Logo Wordpress.

\section{PERMASALAHAN}

Fenomena pengangguran yang terjadi di Negara kita merupakan masalah utama yang dihadapi oleh pemerintah. Terhitung banyak jumlah pengangguran yang terus meningkat tiap harinya. Ini merupakan bukti nyata di Indonesia antara pencari kerja dan pencipta kerja tidak berimbang. Kondisi tersebut disebabkan karena sedikitnya lapangan pekerjaan yang ada saat ini. Bisa jadi pendidikan di Indonesia telah melahirkan para lulusan dengan nilai terbaik dan siap memasuki ke pasar kerja, namun kondisi yang terjadi ialah kenaikan jumlah lapangan kerja kalah cepat dengan kenaikan jumlah lulusan. Oleh karna itu, pemerintah pun menyadari perlunya menanamkan jiwa-jiwa entrepreneurship kepada para generasi muda di Indonesia dengan memberikan pembelajaran sejak dini mengenai entrepreneurship kepada para pelajar mulai dari pendidikan tingkat menengah, tingkat atas bahkan sampai jenjang perguruan tinggi.

Perguruan Tinggi Raharja merupakan sebuah Perguruan Tinggi yang berfokus pada bidang teknologi informasi dan komunikasi. Dalam melaksanakan metode pembelajaran, Perguruan Tinggi Raharja sangat memanfaatkan kemajuan dari teknologi informasi dan komunikasi tersebut. Teknologi di dalam dunia pendidikan merupakan bagian dari konsep teknologi pendidikan, berupa media untuk memperlancar kegiatan belajar mengajar. Penggunaan teknologi dalam pendidikan berhubungan dengan usaha untuk meningkatkan produktivitas pendidikan. Hal ini terbukti dengan adanya TPi (Ten Pilar iLearning) yang mendukung proses kegiatan belajar mengajar di Perguruan Tinggi Raharja.

Namun ada beberapa mata kuliah pada Perguruan Tinggi Raharja yang dirasa masih sangat minim pemanfaatan teknologinya dalam proses pembelajaran. Salah satunya adalah mata kuliah entrepreneur. Hal ini terlihat pada kegiatan entrepreneurship yang masih menggunakan cara-cara konvensional dalam prakteknya. Dimana mahasiswa melakukan kegiatan entrepreneurship secara konvensional dikampus tanpa 
memanfaatkan kemajuan teknologi informasi. Yaitu berdagang secara langsung dalam ruang lingkup kampus.

Dengan ruang lingkup penjualan tersebut, maka berdampak juga pada jangkauan pemasaran produk mereka. Sehingga mereka akan menemui kesulitan dalam mengembangkan produk dagang mereka. Ecommerce merupakan solusi terbaik yang mampu dimanfaatkan dalam kegiatan entrepreneurship pada Perguruan Tinggi Raharja. Sehingga mampu memfasilitasi mahasiswa dalam melakukan kegiatan entrepreneurship yang memanfaatkan kemajuan dalam bidang teknologi informasi.

Berdasarkan penjelasan diatas, dirumuskan beberapa permasalahan yaitu sebagai berikut :

1. Bagaimana praktek kegiatan entrepreneurship yang berjalan?

2. Bagaimana menerapkan konsep pembelajaran yang memanfaatkan kemajuan teknologi informasi pada praktek kegiatan entrepreneurship ?

3. Apakah Zpreneur efektif untuk menjadi solusi pada praktek kegiatan entrepreneurship tersebut?

\section{LITERATURE REVIEW}

Banyak penelitian yang sebelumnya dilakukan mengenai pemanfaatan teknologi informasi dan komunikasi dalam dunia pendidikan. Dengan memanfaatkan internet untuk mengeksplorasi pendidikan. Dalam upaya mengembangkan zpreuner ini perlu dilakukan studi pustaka sebagai salah satu dari penerapan metode penelitian yang akan dilakukan. Diantaranya adalah mengidentifikasikan kesenjangan (identify gaps ), menghindari pembuatan ulang ( reinventing the wheel), mengidentifikasikan metode yang pernah dilakukan, meneruskan penelitian sebelumnya, serta mengetahui orang lain yang spesialisasi dan area penelitiannya sama dibidang ini. Beberapa Literature review tersebut adalah sebagai berikut :

1. Penelitian ini dilakukan oleh Untung Rahardja, Muhamad Yusuf dan Qurotul Aini dari Perguruan Tinggi Raharja pada tahun 2014 yang berrjudul "Aplikasi Campus Learning System iOU (integrated Online Ujian) Dalam Mendukung Kegiatan iLearning Education (iDu) Pada Perguruan Tinggi”. Penelitian ini membahas mengenai alternatif pemecahan masalah ujian yang masih menggunakan paper based dengan menerapkan Campus Learning System iOU (integrated Online Ujian) berbasis computer based pada Perguruan Tinggi Raharja . Dengan iOU yang berbasis computer based mahasiswa dapat mengerjakan soal- soal ujian pada komputer yang merandom soal-soal tersebut, yang juga menjadikan mahasiswa dapat mengerjakan soal dalam waktu yang bersamaan tetapi masing-masing mengerjakan soal berbeda. Dalam pengerjaan soal iOU juga terdapat batas waktu memulai dan mengakhiri soal-soal tersebut. Dan mahasiswa beserta dosen dapat langsung mengetahui nilai akhir dari pengerjaan soal-soal ujian tersebut [1].

2. Penelitian ini dilakukan oleh Ahmad Muhsin dari UPN "Veteran" Yogyakarta yang berjudul "Aplikasi Technopreneurship Untuk Mengembangkan Industri Kecil Melalui Penggunaan Teknologi ECommerce Berbasis Content Management System". Penelitian ini membahas mengenai perbedaan 
antara entrepreneurship dengan technopreneurship yaitu terletak pada penerapan teknologi dalam proses wirausaha. Dan tujuan penelitian ini adalah untuk menerapkan Technopreneurship didalam industri nyata yang berfungsi menjembatani kebutuhan industri kecil terhadap kebutuhan teknologi dalam membantu produktivitas usahanya. Media yang digunakan dikemas dalam teknologi website e-commerce untuk menyelesaikan kebutuhan proses bisnis berbasis ICT (Information Communication Technology). Situs E-Commerce bertujuan untuk menghasilkan situs yang secara otomatis mampu memperkenalkan industry kecil secara online, dapat menjangkau berbagai wilayah diseluruh dunia, dan mampui beroperasi selama 24 jam non-stop [2].

3. Penelitian ini dilakukan oleh Untung Rahardja, Meta Amalya Dewi dan Winiarti Prastiwi dari Perguruan Tinggi Raharja pada tahun 2014 yang berjudul "Implementasi Widuri Sebagai Media Penyimpanan Laporan Dari Referensi Digital Karya Ilmiah". Penelitian ini membahas mengenai pemanfaatan Widuri sebagai tempat penyimpanan laporan $\mathrm{kkp} / \mathrm{ta} / \mathrm{skripsi}$ dan menjadikan referensi yang ada dapat diakses secara online. Dengan mengimplementasikan widuri sebagai penyimpanan laporan KKP/TA/SKRIPSI dapat mempermudah mahasiswa dalam membuat laporan serta mencari referensi [3].

4. Penelitian ini dilakukan oleh Joki Sutrisno dari Universitas Budi Luhur pada tahun 2011 yang berjudul
"Strategi Pengembangan Teknologi Ecommerce Dengan Metode SWOT :Studi Kasus: PT. CHINGMIX BERHAN SEJAHTERA". Dalam Penelitian ini dikatakan bahwa untuk mengimplementasi e-commerce dalam mendukung bisnis suatu organisasi perlu memperhatikan 5 komponen utama, yaitu : pengembangan produk, promosi, transaksi online, product delivery dan after sales support. 5 komponen tersebut akan saling mendukung satu dengan yang lainnya untuk memperoleh revenue dan profit yang lebih baik [4].

5. ini dilakukan oleh Untung Rahardja, Sudaryono dan Irwan Nurdin dari Perguruan Tinggi Raharja pada tahun 2014 yang berjudul "Implementasi IME (iLearning Media) dalam medukung sistem pembelajaran iLearning pada Perguruan Tinggi". Penelitian ini membahas mengenai sistem pembelajaran iLearning pada Perguruan Tinggi Raharja. Sistem iLearning adalah metode perkuliahan di Perguruan Tinggi Raharja yang menggunakan media iPad untuk mempermudah proses pembelajaran mahasiswa. Dengan adanya metode ini maka mahasiswa dapat belajar, bekerja, berdoa dan bermain dengan iPad. Istilah tersebut dikenal dengan nama 4B. iLearning Media atau disingkat dengan nama iMe adalah aplikasi berupa site yang dibuat dan dapat digunakan oleh seluruh mahasiswa Perguruan Tinggi Raharja untuk mengeksplor kreativitasnya dalam belajar. Ini merupakan sistem pembelajaran online yang memudahkan mahasiswa dalam belajar, karena dapat dilakukan di manapun dan kapanpun. 
Maka disimpulkan bahwa kontribusi iMe dapat dijadikan media informasi untuk sistem pembelajaran bagi seluruh civitas Perguruan Tinggi Raharja [5].

6. Penelitian ini dilakukan oleh Iwan Hermawan dari Politeknik Negeri Semarang pada tahun 2011 yang berjudul "Rancangan Pembelajaran Interaktif Mata Kuliah E-commerce Melalui Pembuatan Software Bantu Pengajaran Berbasis Multimedia". Penelitian ini membahas mengenai pemanfaatan teknologi yang dikemas ke dalam sebuah set perangkat multimedia yang dapat digunakan untuk bahan ajar pada mata kuliah ECommerce. Arah dari dikembangkannya perangkat modul digital adalah untuk menunjang perubahan kurikulum berupa penajaman mata kuliah untuk mendapat aspek kognitif-edukatif [6].

7. Penelitian ini dilakukan oleh Untung Rahardja, Khanna Tiara dan Ray Indra Taufik Wijaya dari Perguruan Tinggi Raharja pada tahun 2014 yang berjudul "Penerapan Rinfo Sebagai Media Pendukung Untuk Proses Pembelajaran Pada Perguruan Tinggi Raharja". Penelitian ini membahas mengenai perpaduan antara teknologi dengan pendidikan menjadi sebuah invoasi baru dalam dunia pendidikan. Inovasi tersebut telah diterapkan oleh Perguruan Tinggi Raharja, yaitu dengan digunakannya metode iLearning (Integrated Learning) dalam proses pembelajarannya.

Dimana pembelajaran tersebut sudah berbasis online. Metode iLearning ini terdiri dari TPi (Ten Pilar IT iLearning) atau 10 pilar IT iLearning. Rinfo adalah salah satu dari sepuluh pilar tersebut, dimana Rinfo ini menjadi email resmi yang digunakan oleh seluruh civitas yang ada di Perguruan Tinggi Raharja untuk saling berkomunikasi. Rinfo ini adalah Gmail, yang di adaptasi dari Google Platform dengan ciri khas raharja.info sebagai domainnya. Rinfo ini adalah media komunikasi sekaligus alat pendukung dalam proses pembelajaran di Perguruan Tinggi Raharja. Karena selain terintegrasi dengan TPi, Rinfo ini pun terhubung pula dengan alat penunjang pembelajaran lainnya, seperti Docs, Drive, Sites, dan alat penunjang lainnya [7].

8. Penelitian ini dilakukan oleh Novi Hidayati dari Universitas Budi Luhur pada tahun 2010 yang berjudul "Sistem E-Learning Untuk Meningkatkan Proses Belajar Mengajar : Studi Kasus Pada SMA Negeri 10 Bandar Lampung". Dalam penelitian tersebut menjelaskan pada hakekatnya E-Learning adalah bentuk pembelajaran konvensional yang dituangkan dalam format digital melalui teknologi internet. Namun disamping itu juga harus memegang prinsip pembelajaran. [8]

9. Penelitian ini dilakukan oleh Untung Rahardja, Meta Amalya Dewi dan Fitri Lisnawati dari Perguruan Tinggi Raharja pada tahun 2014 yang berjudul "Kinerja iLearning Raharja Ask And News (IRAN) Dalam Mendukung Kegiatan Tridharma iDUHelp!". Penelitian ini membahas mengenai pemanfataan IRAN dalam mendukung sistem pelayanan iDuHelp! guna memudahkan pribadi Raharja dalam melakukan Tridharma Perguruan Tinggi[9]. 
10. Penelitian ini dilakukan oleh Untung Rahardja,Qurotul Aini dan Desi Sartika dari Perguruan Tinggi Raharja pada tahun 2014 yang berjudul "Build A Business To Consumer Online Store Using Airzone Content Management System". Penelitian ini membahas mengenai pemanfaatan IRAN dalam mendukung sistem pelayanan iDuHelp! guna memudahkan pribadi Raharja dalam melakukan Tridharma Perguruan Tinggi[9].

Dari sepuluh literature review yang ada, telah banyak penelitian yang telah membahas pemanfaatan kemajuan teknologi informasi untuk meningkatkan efektifitas dalam suatu manajemen, baik pemanfaatan untuk bidang bisnis maupun edukasi. Namun dapat disimpulkan pula bahwa belum ada peneliti yang secara khusus membahas mengenai pemanfaatan suatu content management system ecommerce berbasis web yang mampu mendukung kegiatan entrepreneurship dalam mata kuliah entrepreneur di perguruan tinggi..

\section{PEMECAHAN MASALAH}

Untuk menangani masalah diatas, maka diperlukan suatu sistem yang mampu mendukung sistem pembelajaran pada mata kuliah entrepreneur. Sistem tersebut adalah Zpreuner, merupakan sebuah sistem yang dibangun untuk keperluan mata kuliah entrepreneur. Sistem ini memfasilitasi mahasiswa yang sedang menempuh mata kuliah entrepreneurship dalam menjalani kegiatan entrepreneur di Perguruan Tinggi Raharja.

Sistem ecommerce Zpreneur yang dikembangkan oleh Perguruan Tinggi Raharja bertujuan untuk memenuhi aktivitas kegiatan mahasiswa dalam melakukan kegiatan entrepreneurship. Dimana mahasiswa bisa mendaftarkan diri dan memiliki sebuah toko online mereka masing-masing. Dengan bantuan sistem tersebut, memudahkan mereka dalam melakukan aktivitas entrepreneur guna menjual dan memasarkan produk mereka.

Setiap pribadi Raharja maupun user luar bisa melakukan registrasi pada sistem zpreneur tersebut, dalam sistem zpreuner terdapat 2 jenis registrasi yang tersedia untuk para user. Yang pertama yaitu registrasi untuk seorang customer. Seorang customer hanyalah seorang user biasa yang telah melakukan kegiatan shoping pada sistem zpreuner dan mendaftarkan diri didalamnya, akan tetapi tanpa mendaftarkan diripun mereka bisa langsung memesan produk di zpreuner. Yang ke 2 yaitu registrasi untuk menjadi seorang seller. Cara melakukan registrasi ini pun mirip dengan registrasi seorang customer, hanya saja ketika ingin menjadi seller, si user wajib melakukan request melalui iDuHelp! dan meminta PIC zpreuner untuk menjadikannya seorang seller.

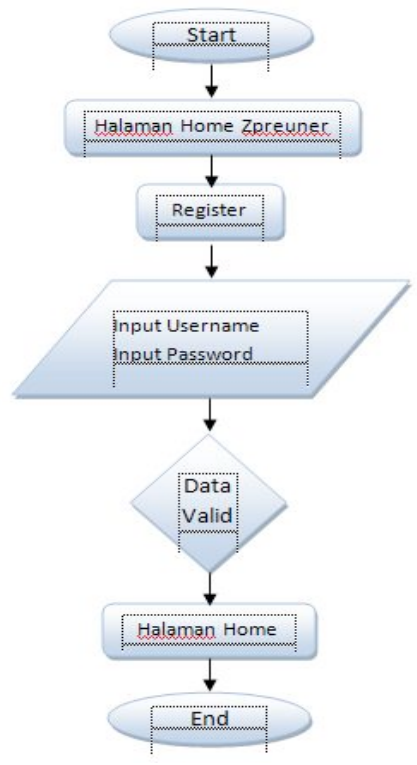

Gambar 6. Flowchart Proses Registrasi Zpreuner. 
Dalam penerapannya Content Management System Ecommerce Zpreuner mengadopsi karakteristik B2C. Penerapan ecommerce dengan model B2C pada salah satu mata kuliah entrepreuner iLearning di perguruan tinggi Raharja ini amat sangat diperlukan agar dapat membantu dan menyediakan sebuah wadah bagi para mahasiswa dalam melakukan pemasaran produk. E-commerce dengan model tersebut juga dikombinasikan dengan Sistem Informasi Berbasis Web sehingga proses interaksi terhadap pihakpihak yang terkait didalamnya dapat dilakukan melalui media internet. Dengan menerapkan content management system zpreuner yang berorientasi pada model ecommerce B2C maka akan memberikan solusi bagi para mahasiswa untuk mejalankan bisnisnya tanpa perlu memikirkan batasan wilayah pemasaran produk.

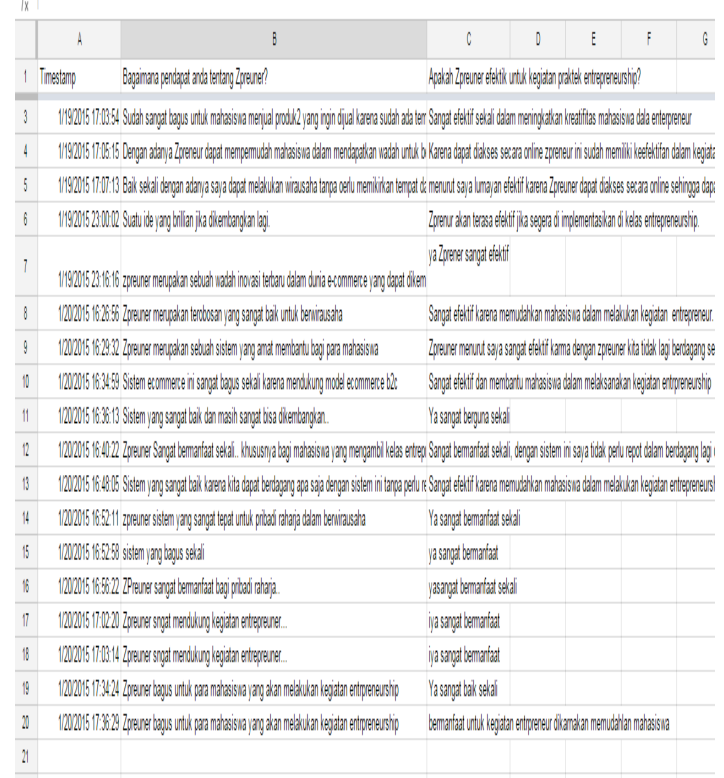

Gambar 7. Respon Survey Zpreuner.

Gambar 7 merupakan hasil survey yang dilakukan terhadap 20 mahasiswa mengenai keunggulan menggunakan sistem zpreuner dalam praktek entrepreneurship dibandingkan menggunakan cara konvensional.

\section{IMPLEMENTASI}

Tampilan implementasi aplikasi ecommerce zpreuner memliki berbagai maca fitur yang dapat digunakan oleh pribadi Raharja dalam melaksanakan kegiatan entrepreneur yang terdiri dari :

\section{A.Tampilan Newsletter Zpreuner}

Fitur newsletter zpreuner. Ketika pertama kali anda mengakses sistem zpreuner, anda akan menemui sebuah popup news. Pop up tersebut ialah newsletter zpreuner, ini memungkinkan anda bergabung bersama komunitas zpreuner. User dapat menjadi subcriber zpreuner, dengan begitu, mereka akan mendapatkan segala macam info terbaru dari zpreuner ke email mereka masing masing. Baik itu promosi, pemberitahuan, iklan dan lain-lain.

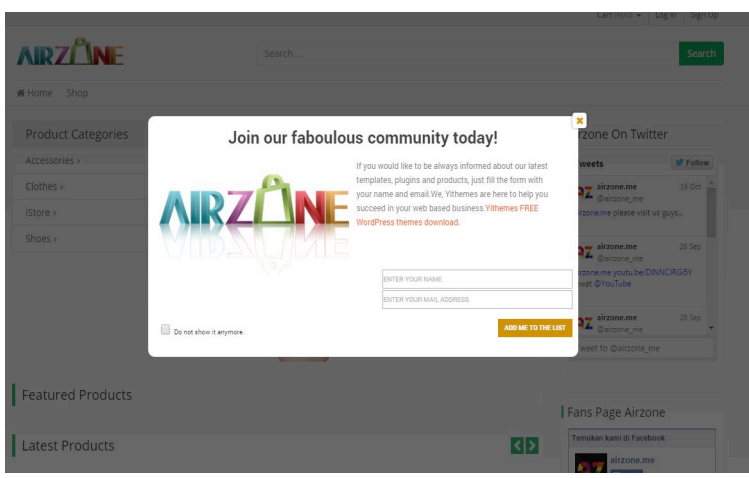

Gambar 8. Pop up Newsletter Zpreuner.

\section{B.Tampilan Utama Sistem Zpreuner}

Aplikasi Zpreuner dapat diakses darimana saja dan kapan saja oleh siapapun. Tampilan yang sederhana dan user friendly, memudahkan user untuk dapat menggunakannya. Terdapat kategori menu, slider, fitur produk, twiiter airzone dan masih banyak yang terdapat pada halaman utama. 
ISSN : 1978 -8282

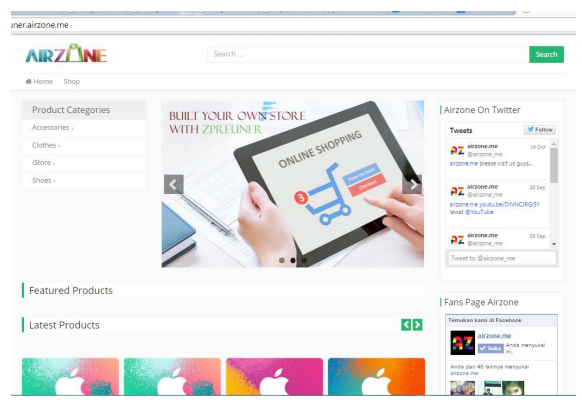

Gambar 9. Tampilan Utama Zpreuner

\section{C.Tampilan List Produk}

Tampilan list produk pada halaman utama zpreuner menampilkan produkproduk yang dijual oleh para seller airzone. Kategor list produk yang terdapat pada halaman utama airzone menampilkan produk-produk terbaru yang dijual, produkproduk dengan penjualan terbanyak, produkproduk yang mempunyai rating terbaik dari customer dll.

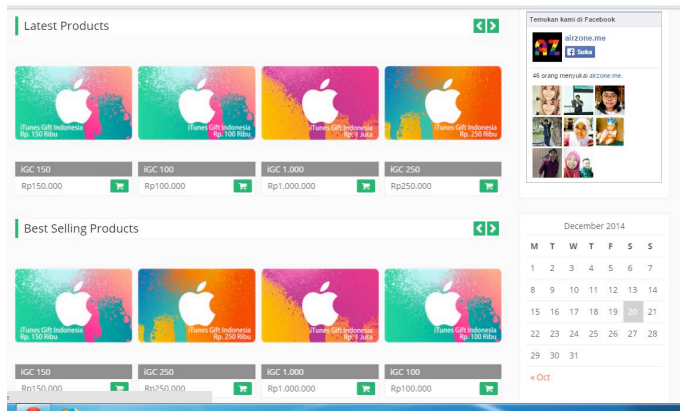

Gambar 10. Tampilan List Produk di halaman utama Zpreuner.

\section{D.Tampilan Toko User}

Setiap seller di sistem zpreuner dapat memilik tokonya sendiri masing-masing. Sistem zpreuner menyediakan toko untuk tiap seller, dan memungkinkan mereka mengatur toko mereka sendiri. Pada halaman toko user ini, terdapat informasi mengenai toko online seller, lokasi, serta produk-produk yang mereka jual di situs zpreuner.

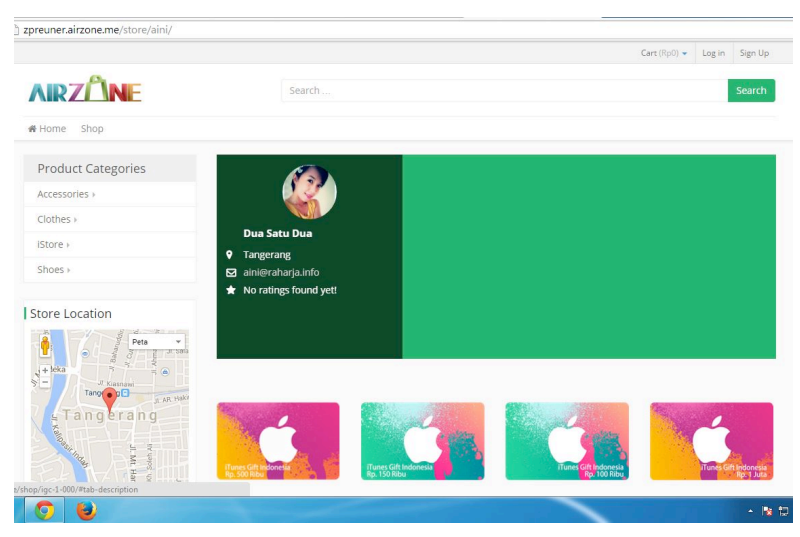

Gambar 11. Tampilan Toko Online Seller.

\section{E.Halaman Account Customer}

Ketika seorang customer ingin melakukan pembelian di zpreuner untuk kedua kalinya dilain waktu. Alangkah baiknya mereka mendaftarkan diri di zpreuner, karna dengan begitu mereka dapat menyimpan alamat pengiriman mereka tanpa harus mengisi form kembali ketika melakukan pembelian lagi. Halaman Account Customer ini berisi informasi shipping customer, history pesanan barang customer, informasi data diri customer.

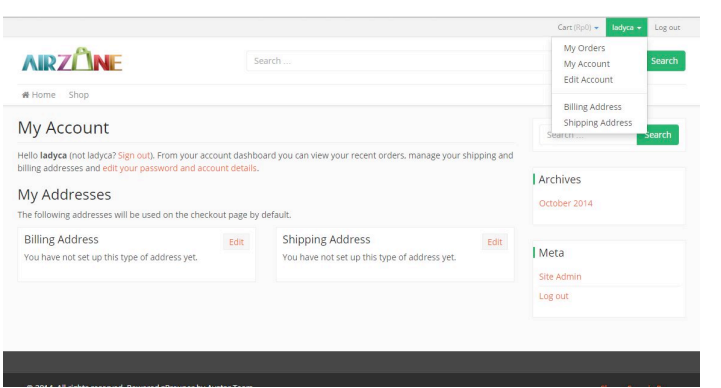

Gambar 12. Tampilan Halaman member Customer.

\section{F.Halaman Cart}

Halaman keranjang belanja (cart) menyimpan informasi produk yang dibeli oleh para customer. Halaman ini menampung produk yang telah di pilih oleh 
para customer sebelum customer memutuskan melakukan pembelian dan melanjutkan ke proses selanjutnya, yaitu konfirmasi pembelian dan pengisian data diri. Pada halaman ini terdapat informasi mengenai prouk apa saja yang dipilih customer, quantity dari masing masing item produk, jumlah harga per item produk serta jumlah keseluruhan harga.

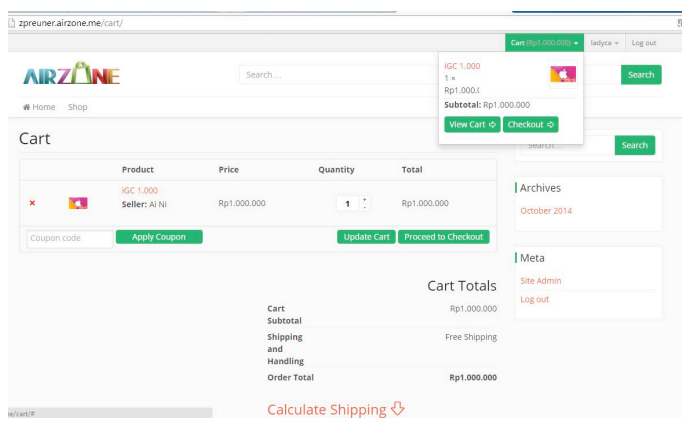

Gambar 13. Tampilan Halaman Cart.

\section{G.Halaman Check Out}

Halaman check out berisi form-form untuk memenuhi data customer yang telah melakukan pemesanan dan pembelia di zpreuner. Form tersebut mencakup, data diri dan alamat tujuan pengiriman barang.

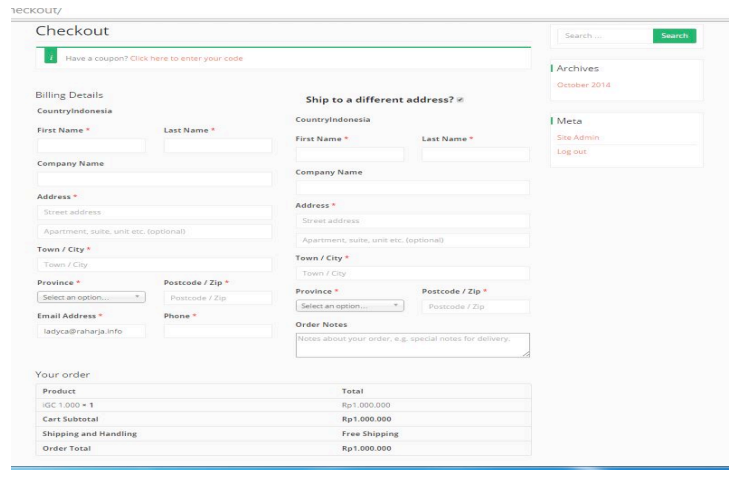

Gambar 14. Tampilan Halaman Checkout.

\section{KELEBIHAN}

Dengan penerapan sistem aplikasi zpreuner ini, diharapkan dapat membantu mahasiswa Perguruan Tinggi Raharja yang sedang menempuh mata kuliah entrepreneurship dalam melakukan kegiatan entrepreneurship di Perguruan Tinggi Raharja. Beberapa kelebihan dari sistem aplikasi zpreuner ini adalah sebagai berikut :

1. Dengan zpreuner, proses kegiatan entrepreneurship dapat berjalan dengan mudah, praktis dan menyenangkan.

2. Menghemat waktu bagi customer untuk berbelanja.

3. Memungkinkan seller memiliki toko onlinenya masing-masing.

4. User Friendly.

5. Memudahkan seller dalam menjual produk mereka.

6. Memberikan kemudahan bagi seller dalam memperluas pangsa pasar.

7. Memiliki sistem jual beli online yang memudahkan seller maupun customer.

8. Dapat menampung banyak seller dalam 1 sistem.

9. Dapat memberikan presentase keuntungan untuk tiap seller.

10. Seller dapat menata toko online mereka sendiri.

\section{KEKURANGAN}

1. Dalam mengakses aplikasi zpreuner ini memerlukan jaringan internet untuk dapat melakukan transaksi jual beli secara online antara penjual dan pembeli.

2. Sampai saat ini aplikasi zpreuner belum bisa menghitung biaya kirim dengan menggunakan jasa pengiriman seperti JNE, TIKI atau yang lainnnya. Saat ini biaya pengiriman masih dihitung berdasarkan flat rate ke semua wilayah diseluruh Indonesia. 
3. Belum ada view page count otomatis untuk toko masing-masing seller. sehingga toko seller mana yang paling banyak dikunjungi oleh customer masih belum bisa dihitung secara otomatis dan dijadikan laporan.

4. Seller belum bisa mengganti theme untuk masing-masing toko online mereka. Seller hanya bisa mengganti image banner pada toko online mereka. Sehingga theme untuk masing-masing toko online seller sama. Yang membedakan hanya image banner mereka di masingmasing toko.

\section{KESIMPULAN}

Praktek kegiatan entrepreneurship yang sedang berjalan di Perguruan Tinggi Raharja saat ini masih amat konvensional. Para mahasiswa melakukan kegiatan praktek entrepreneur seperti berdagang diarea kampus dengan membawa produk dagangan mereka. Dengan cara seperti ini, tentu saja banyak kekurangan yang didapatkan. Contohnya para mahasiswa lebih dipersulit karna harus membawa bawa barang dagangan mereka kemanapun mereka pergi, cara proses menjual mereka menghabiskan banyak tenaga, dan tentunya area pemasaran mereka hanya di ruang lingkup kampus. Untuk melakukan kegiatan entrepreneurship dengan lebih baik perlu dibangun suatu sistem yang mampu menangani masalah yang dihadapi oleh para mahasiswa. Penerapan Content Management System Ecommerce Zpreuner dalam mendukung kegiatan entrepreneurship mahasiswa di Perguruan Tinggi Raharja merupakan solusi yang terbaik. Sistem Zpreuner merupakan sebuah sistem ecommerce berbasis web yang mampu membantu mahasiswa dalam melakukan kegiatan entrepreneur. Para mahasiswa difasilitasi sebuah wadah bagi mereka untuk menjual produk-produk mereka. Zpreneur memungkinkan para mahasiswa untuk dapat memiliki toko online nya masing-masing. Sistem zpreneur sangat efektif digunakan untuk para mahasiswa yang kesulitan dalam melakukan kegiatan entrepreneur di mata kuliah entrepreneurship karena sistem ini memungkinkan mereka memiliki toko online mereka masing-masing. Para seller dapat mengupload produk mereka di toko online mereka dan dapat memasarkan produk mereka melalui media sosial. Dengan begitu, proses pemasaran yang mereka lakukan menjadi lebih mudah dan juga jangkauan pemasaran mereka menjadi lebih jauh. bahkan tidak menutup kemungkinan mereka dapat menjual produk dagangan mereka ke seluruh pelosok Nusantara. Tentunya cara ini dinilai lebih efektif bagi para mahasiswa dalam melaksanakan kegiatan entrepreneurship.

\section{DAFTAR PUSTAKA}

1. Hermawan Iwan "Rancangan Pembelajaran Interaktif Mata Kuliah E-commerce Melalui Pembuatan Software Bantu Pengajaran Berbasis Multimedia", 2011. Politeknik Negeri Semarang.

2. Hidayati Novi "Sistem E-Learning Untuk Meningkatkan Proses Belajar Mengajar : Studi Kasus Pada SMA Negeri 10 Bandar Lampung”, 2013. Universitas Budi Luhur.

3. Ahmad, "Aplikasi Technopreneurship Untuk Mengembangkan Industri Kecil Melalui Penggunaan Teknologi ECommerce Berbasis Content Management System", UPN "Veteran" Yogyakarta. 
4. Rahardja Untung, Aini Qurotul, Sartika Desi "Build A Business To Consumer Online Store Using Airzone Content Management System", 2014, Perguruan Tinggi Raharja.

5. Rahardja Untung, Amalya Dewi Meta, Lisnawati Fitri "Kinerja iLearning Raharja Ask And News (IRAN) Dalam Mendukung Kegiatan Tridharma iDUHelp!”, 2014, Perguruan Tinggi Raharja.

6. Untung, Amalya Dewi Meta, Prastiwi Winiarti "Implementasi Widuri Sebagai Media Penyimpanan Laporan Dari Referensi Digital Karya Ilmiah", 2014, Perguruan Tinggi Raharja.

7. Rahardja Untung, Sudaryono, Nurdin Irwan "Implementasi IME (iLearning Media) dalam medukung sistem pembelajaran iLearning pada Perguruan Tinggi”, 2014, Perguruan Tinggi Raharja.

8. Rahardja Untung, Tiara Khanna, Indra Taufik Wijaya Ray "Penerapan Rinfo Sebagai Media Pendukung Untuk Proses Pembelajaran Pada Perguruan Tinggi Raharja”, 2014, Perguruan Tinggi Raharja.

9. Rahardja Untung, Yusuf Muhammad, Aini Qurotul "Aplikasi Campus Learning System iOU (integrated Online Ujian) Dalam Mendukung Kegiatan iLearning Education (iDu) Pada Perguruan Tinggi", 2014, Perguruan Tinggi Raharja.

10. Sutrisno Joki, "Strategi Pengembangan Teknologi Ecommerce Dengan Metode SWOT :Studi Kasus: PT. CHINGMIX BERHAN SEJAHTERA”, 2011, Universitas Budi Luhur. 